\title{
Pengaruh Corporate Governance terhadap Manajemen Laba (study kasus pada Bank BRI, Bank BNI, Bank Mandiri, Bank Danamon, Bank BCA dan Bank Bukopin Tbk)
}

\author{
Zaki Arif Maulana, Desfriana Sari \\ STIE "KBP" PADANG \\ takursing307@gmail.com
}

\begin{abstract}
The purpose of this research is to know the effect of Corporate governance (managerial ownership, institutional ownership, audit quality, independent commissioner) to Earnings Management at PT. BRI, Bank BNI, Bank Mandiri, Bank Danamon, Bank BCA, Bank Bukopin Tbk. The test conducted in this study are assumption test, multiple linear analysis, hypothesis test and coefficient of determination test.Based on partial hypothesis test ( $t$ test) managerial ownership, institutional ownership, have positive and significant effect to earnings management. audit quality has a negative and significant effect on earnings management. while independent commissioners have no effect on earnings management. Based on hypothetical test simultaneously ( $f$ test) Managerial Ownership, Institutional Ownership, Audit Quality, Independent Commissioner have significant influence to earnings management.
\end{abstract}

Keywords: Corporate governance (managerial ownership, institutional ownership, audit quality, independent commissioner) and Profit Management

\section{PENDAHULUAN}

Tata kelola perusahaan di setiap perusahaan merupakan konsep yang penting dalam peningkatan kinerja di suatu perusahaan dan dilakukan oleh supervisi kinerja perusahaan. Dengan menjamin akuntabilitas manajemen demi kepentingan untuk memegang peraturan yang berdasarkan kerangka peraturan itu sendiri. Tata kelola perusahaan bertujuan untuk mencapai pengelolahan laporan keuangan yang transparan dalam pengelolahan suatu perusahaan. Jika konsep ini berjalan dengan baik dan semestinya akan berdampak pada perekonomian yang terus tumbuh dengan transparan pengelolahan perusahaan terwujud dan dapat menguntungkan semua belah pihak.

Ada isu yang beredar tentang tata kelola perusahan (corporate governance). Pada tahun 1998 di indonesia bersamaan krisis yang berkelanjutan. Pada saaat itu perbaikan mengalami kelambanan yang disebabkan oleh kurangnya konsep tata kelola perusahaan yang ada di indonesia. Pemerintah dan investor mulai memperhatikan konsep ini setelah mengetahui konsep tata kelola perusahaan yang lemah.

FCGI tahun 2003 atau Forum For Corporate Govermance in Indonesian) mengatakan konsep tata kelola perusahaan akan memberikan perlindungan yang efektif untuk investor maupun kreditor supaya mereka mendapatkan return atas investasi yang dikelola dengan baik. Corporate governance mampu untuk menciptakan lingkunagn yang kondusif guna pertumbuhan efektif dan efisien pada sektor korporat. Konsep ini juga dapat dikatakan sebagai susunan yang berisi aturan tertentu antara hubungan para investor, manajer, kreditor, pemerintah, antar karyawan maupun penganggung jawab di lingkungan internal maupun eksternal. 


\section{KAJIAN TEORI}

\section{Defenisi Manajemen Laba}

Pengertian laba yang dianut oleh struktur akuntansi didefinisikan sebagai pembedaan antara pendapatan yang direalisasikan dari transaksi yang terjadi selama satu periode dengan biaya yang berkaitan dengan pendapatan tersebut (A. Chariri dan Imam Ghozali, 2001) Informasi akuntansi harus dapat memenuhi kebutuhan semua pihak yang akan menggunakannya dan bebas dari ketergantungan dan keinginan pihak-pihak tertentu. Informasi laba juga harus komprehensif untuk mengungkapkan semua fakta baik transaksi maupun peristiwa yang dialami perusahaan selama satu periode.

\section{Defenisi Corporate Governance}

Corporate governance merupakan konsep yang didasarkan pada teori keagenan, diharapkan bisa berfungsi sebagai alat untuk memberikan keyakinan kepada para investor bahwa mereka akan menerima return atas dana yang telah mereka investasikan (Herawaty, 2008). Corporate Governance adalah konsep yang diajukan demi peningkatan kinerja perusahaan melalui supervisi dan monitoring kinerja manajemen dan menjamin akuntabilitas manajemen terhadap stakeholder dengan mendasarkan pada kerangka peraturan.

Kepemilikan institusional adalah kepemilikan saham perusahaan yang dimiliki oleh institusi atau lembaga seperti perusahaan asuransi, bank, perusahaan investasi dan kepemilikan institusi lain (Tarjo, 2008). Kepemilikan institusional memiliki peranan yang penting dalam meminimalisasi konflik keagenan yang terjadi antara manajer dan pemegang saham. Keberadaan investor institusional dianggap mampu menjadi mekanisme monitoring yang efektif dalam setiap keputusan yang diambil oleh manajer.

Komisaris independen adalah anggota dewan komisaris yang tidak terafiliasi dengan manajemen, anggota dewan komisaris lainnya dan pemegang saham pengendali, serta bebas dari hubungan bisnis atau hubungan lainnya yang dapat mempengaruhi kemampuannya untuk bertindak independen atau bertindak demi kepentingan perusahaan (Komite Nasional Kebijakan Governance (KNKG), Dewan komisaris adalah sebuah dewan yang bertugas untuk melakukan pengawasan dan memberikan nasihat kepada direktur Perseroan Terbatas (PT). Ukuran Dewan Komisaris merupakan jumlah dewan komisaris yang dimiliki oleh sebuah perusahaan dalam menjalankan fungsi monitoring dari implementasi kebijakan direksi

\section{Hipotesis}

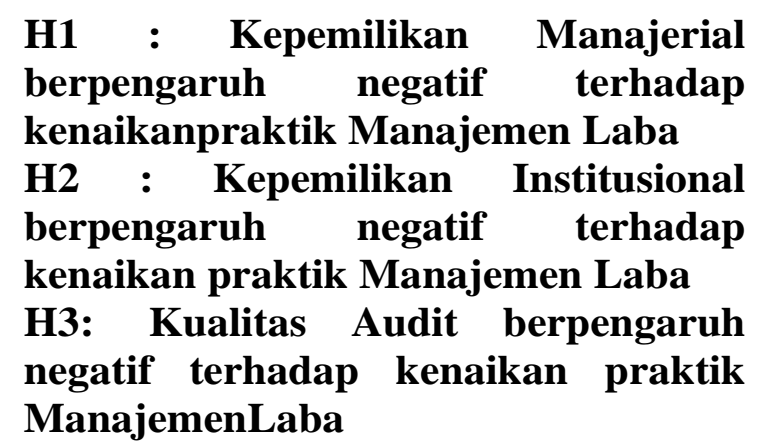

\section{METODE PENELITIAN}

\section{Jenis Penelitian}

Penelitian ini merupakan penelitian kuantitatif yang menekankan pada pengujianteori melalui pengukuran variabel penelitian dengan angka dan melakukan analisis data dengan prosedur statistik. Penelitian ini menggunakan penelitian kuantitatif, karena penelitian ini bersifat menganalisa laporan keuangan perusahaan perbankan yang tercatat pada BEI dan menafsirkan hasilnya dalam bentuk angka-angka. 


\section{Penentuan Sampel}

Menurut (Ferdinand, 2014) sampel adalah subset dari populasi, terdiri dari beberapa anggota populasi. Subset ini diambil karena dalam banyak kasus tidak mungkin kita meneliti seluruh anggota populasi oleh karena itu, kita membentuk sebuah perwakilan populasi yang disebut sampel. Sampel dalam penelitian ini adalah beberapaperusahaan perbankan yang ada di BEI yang memenuhi kriteria.

\section{Populasi}

Menurut (Ferdinand, 2014) yang dikatakan populasi adalah gabungan dari seluruh elemen yang berbentuk peristiwa, hal atau orang yang memiliki karateristisk yang serupa menjadi pusat perhatian seorang peneliti karena itu dipandang sebagai sebuah semesta penelitian. (Sugiyono, 2014) juga mendefenisikan bahwa populasi merupakan suatu wilayah generalisasi yang terdiri dari objek dan subjek yang memiliki kualitas dan juga karakteristik tertentu yang dapat diterapkan seorang peneliti untuk mempelajarinya dan juga menarik kesimpulan. Maka dari itu populasi yang ada dalam penelitian ini adalah seluruh perusahaan perbankan yang sudah go public yang ada dalam Bursa Efek Indonesia sehingga menemukan populasi Bank BNI, Bank BRI, Bank Mandiri, Bank Danamon, Bank Bukopin dan Bank BCA.

\section{Jenis dan Sumber Data}

Sumber data yang digunakan dalam peelitian ini adalah :

Data primer yaitu data atau segala informasi yang diperoleh, diamati dan dicatat olehpeneliti langsung dari objek penelitian, yaitu dengan observasi, wawancara dan kuesioner kepada responden.

Data sekunder yaitu atau informasi yang berasal dari buku-buku, dokumen perusahaan , jurnal, skripsi, serta bacaanbacaan yang berasal dari media cetak lainnyayang berhubungan dengan masalah yang diteliti.

\section{HASIL PENELITIAN}

\section{Hasil Regresi Berganda}

Dari tabel 4.1 diatas dapat dibuat persamaan regresi dari variabel-variabel penelitian ini sebagai berikut :

$\mathrm{Y}=\mathrm{a}+\mathrm{b} 1 \mathrm{X} 1+\mathrm{b} 2 \mathrm{X} 2+\mathrm{b} 3 \mathrm{X} 3+\mathrm{b} 4 \mathrm{X} 4+$ $\mathrm{e}$

$\mathrm{Y}=-8.480+1.250 \mathrm{X} 1+3.331 \mathrm{X} 2+-$ $7.493 \mathrm{X} 3+-0.966 \mathrm{X} 4+\mathrm{e}$

Dari persamaan regresi diatas nilai konstanta $\geq 480$ artinya jika kepemilikan manajerial, kepemilikan institusional, kualitas audit, komisaris independen dialihkan maka manajemen laba nilainya adalah $-8,480$

Nilai koefisien Kepemilikan Manajerial $\left(\mathrm{X}_{1}\right)$ yakni 1.250. Hal ini menunjukan bahwa apabila Kepemilikan Manajerial meningkat sebesar satu-satuan maka Manajemen laba (Y) akan meningkat sebesar 1.250. Dengan asumsi Kepemilikan Institusional, Kualitas Audit, Komisaris Independen tetap.

Nilai koefisien Kepemilikan Institusional $\left(\mathrm{X}_{2}\right)$ adalah 3.331. Hal ini menunjukan bahwa apabila Kepemilikan Institusional meningkat sebesar satu-satuan maka Manajemen laba (Y) akan meningkat sebesar 3.331. Dengan asumsi Kepemilikan Manajerial, Kualitas Audit, Komisaris Independen tetap.

Koefisien Kualitas Audit $\left(\mathrm{X}_{3}\right)$ yakni 7.493. Hal ini menunjukan bahwa apabila Kualitas Audit meningkat sebesar satusatuan maka Manajemen laba (Y) akan menurun sebesar 7.943. Dengan asumsi Kepemilikan Manajerial, Kepemilikan Institusional, Komisaris Independen tetap. 
Koefisien Komisaris Independen $\left(\mathrm{X}_{4}\right)$ yakni -0.966. Hal ini menunjukan bahwa apabila Komisaris Independen meningkat sebesar satu-satuan maka Manajemen laba (Y) akan menurun sebesar -0.966. Dengan asumsi Kepemilikan Manajerial, Kepemilikan Institusional, dan Kualitas Audit tetap.

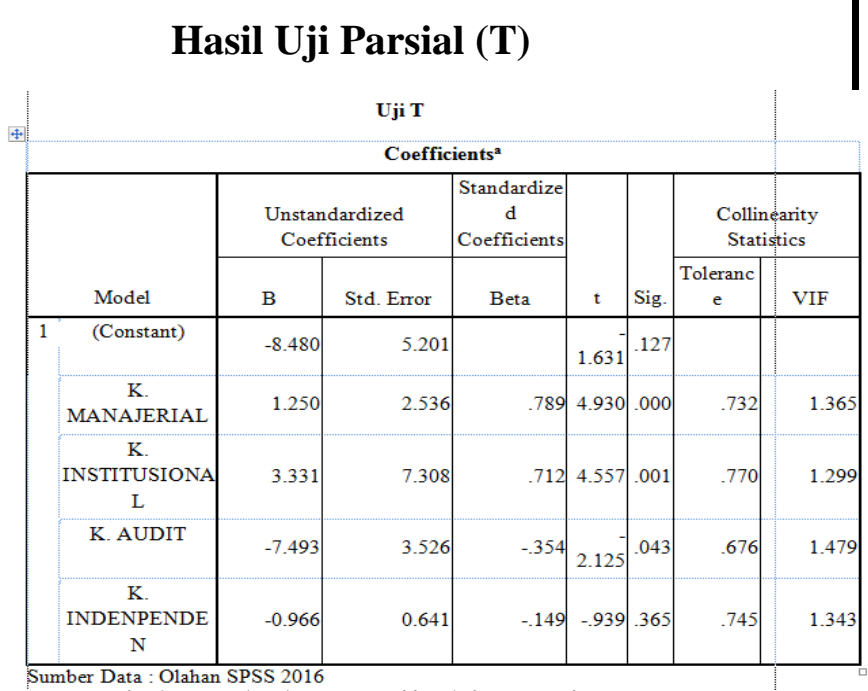

menunjukan bahwa uji hipotesisnya $\mathrm{Ha}$ diterima dan menolak Ho, hal ini dikarenakan nilai Sign $<0.05(0.000<$ 0,05). maka dapat dikatakan secara parsial Kepemilikan Manajerial berpengaruh signifikan terhadap manajemen laba.

Variabel Kepemilikan Institusional menunjukan bahwa uji hipotesisnya $\mathrm{Ha}$ diterima dan menolak Ho, hal ini dikarenakan nilai Sign $<0.05(0.001<$ 0,05). maka dapat dikatakan secara parsial Kepemilikan Institusional berpengaruh signifikan terhadap manajemen laba.

Variabel Kepemilikan Audit menunjukan bahwa uji hipotesisnya $\mathrm{Ha}$ diterima dan menolak Ho, hal ini dikarenakan nilai Sign $<0.05(0.043<0,05)$. maka dapat dikatakan secara parsial Kepemilikan Audit berpengaruh signifikan terhadap manajemen laba.

Variabel Komisaris Independent menunjukan bahwa uji hipotesisnya $\mathrm{Ha}$ diterima dan menolak Ho, hal ini dikarenakan nilai Sign > $0.05(0.365>$ 0,05). maka dapat dikatakan secara parsial Komisaris Independent tidak berpengaruh signifikan terhadap manajemen laba.
Hasil Uji Simultan (F)

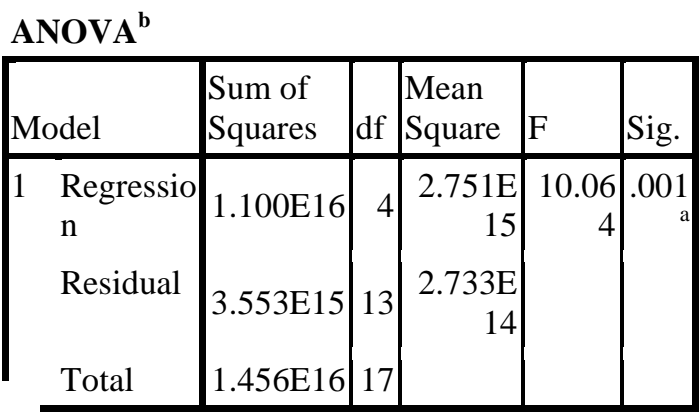

zrdasarkan tabel diatas menunjukkan hwa besar pengaruh secara simultan lalah sebesar 0.756 atau $75.6 \%$, dangkan sisanya $24.4 \%$ dipengaruhi oleh ktor lainnya, seperti harga saham.

\section{ESIMPULAN DAN SARAN}

\section{esimpulan}

Berdasarkan pembahasan dan hasil yang telah dilakukan maka dapat ditarik kesimpulan sebagai berikut ini :

1. Kepemilikan manjerial yang dimana variabel tersebut telah di uji dan menghasilkan hipotesisnya bahwa secara parsial variabel kepemilikan manjerial mempunyai pengaruh yang positif dan juga signifikan terhadap variabel manajemen laba yang dimana variabel kepemilikan manajerial adalah variabel indenpenden (X1) dan manajemen laba adalah variabel dependen (Y).

2. Kepemilikan institusional yang mana variabel tersebut di uji dan mengkasilkan hipotesisnya bahwa secara parsial variabel kepemilikan institusional mempunyai pengaruh yang positif dan juga signifikan terhadap variabel manajemen laba yang dimana variabel kepemilikan institusional adalah variabel indenpenden (X2) dan variabel dependennya adalah manajemen laba. 
3. Variabel ini juga meyimpulkan hasil yang dimana variabel kualitas audit sebagai variabel indenpenden (X3) mempunyai pngaruh posotof dan signifikan terhadap manajemen laba sebagai variabel dependennya.

4. Dan juga variabel komisaris indenpenden juga mempunyai pengaruh positif dan signifikan terhadap variabel dependennya yaitu manajemen laba.

\section{Saran}

Dan berdasarkan defenisi di atas yang telah di bahas dari bab 1 latar belakang sampai dengan bab 4 yang berisi pembahasan maka peniliti memberi beberapa saran yaitu :

1. Untuk pihak perusahaan khususnya bagi industri perbankan

Peneliti mempunyai saran untuk industri perbankan untuk perlu mempertimbangkan cara yang berbeda dengan menggunakan dan menentukan discretionary acrual sehingga dapat melihat adanya manjemen laba dalam sudut yang berbeda.

2. Bagi Peneliti sendiri maupun peneliti selanjutnya

Peneliti menyarankan jika ada yang akan meneliti tentang variabel ukuran perusahaan yang mungkin berpengaruh terhadap manajemen laba serta dapat memasukkan mekanisme sebuah tata kelola perusahaan yang lain contohnya sperti lrbih memilih atau mefokuskan variabel komite sebuah audit dan kompetensi sebuah dewan komisaris.

\section{KATA PENGANTAR}

Syukur Alhamdulillah penulis ucapkan kepada Allah SWT, yang telah memberikan rahmat dan hidayah-Nya, sehingga akhirnya penulis dapat menyelesaikan penelitian ini dengan judul

"Pengaruh Corporate Governance terhadap Manajemen Laba (study kasus pada Bank BRI, Bank BNI, Bank Mandiri, Bank Danamon, Bank BCA dan Bank Bukopin Tbk)"

Untuk itu ucapkan terima kasih yang sebesar- besarnya penulis sampaikan kepada:

1. Bapak Febryandi Ananda,SE,MSi selaku ketua STIE ' KBP' Padang

2. Ibuk Lidya Marta ,SE, MM selaku wakil ketua STIE"KBP" Padang.

3. Ibu Afriyeni, SE, MM selaku direktur AKBP Padang.

4. Ibu Febsri Susanti S.E.I M.M selaku Ketua Program Studi Manajemen Sekolah Tinggi Ilmu Ekonomi ''Keuangan, Perbankan dan Pembangunan' Padang.

5. Ibu Desfriana Sari SE, MM selaku Dosen Pembimbing penulis, yang telah membimbing penulis dari awal skripsi sampai saat sekarang ini, membimbing penulis dengan penuh kesabaran, terimakasih atas segala kesempatan yang ibu berikan semoga nasehat-nasehat yang ibu berikan memberikan manfaat bagi saya.

6. Seluruh dosen yang telah memberikan ilmunya kepada penulis serta seluruh karyawan dan karyawati AKBP-STIE"KBP" Padang

7. Kedua Orang Tua, yang telah membimbing dan memberikan motivasi dari saya mulai menginjakkan kaki di Perguruan Tinggi sampai saya selesai melaksanakan Perguruan Tinggi di kampus STIE'KBP”.

8. Terakhir teman-teman seangkatan BP 13 seperjuangan dalam menjalani perkuliahan sampai akhir menulis skripsi. 


\section{DAFTAR PUSTAKA}

A. Chariri dan Imam Ghozali. (2001). Teori Akuntansi, Yogyakarta: BPFE.

A, N. dan S. Z. (2007). Analisis Pengaruh Kepemilikan Institusional dan Kualitas Audit Terhadap Manajemen Laba. Jurnal Maksi, Vol. 7, No. 1, hal. 19-32.

Afriyeni, A., \& Marlius, D. (2017). Analisis Pengaruh Harga Saham Perdana Terhadap Abnormal Return Yang Diterima Investor Studi Pada Bursa Efek Indonesia. https://doi.org/10.31219/osf.io/8z7hx

Afriyeni, A., \& Marlius, D. (2018). Analisis Pengaruh Informasi Prospektus Perusahaan Terhadap Initial Return Saham Pada Pasar Perdana Di Bursa Efek Indonesia. https://doi.org/10.31219/osf.io/kt6c4

Afriyeni, A., \& Marlius, D. (2019). Analisis Faktor-Faktor Yang Berpengaruh Terhadap Ketepatan Waktu Penyampaian Laporan Keuangan Pada Perusahaan Yang Listing Di Bursa Efek Indonesia. https://doi.org/10.31219/osf.io/rv4qf

Afriyeni, A., \& Marlius, D. (2019). Analisis Tingkat Pengembalian Dan Risiko Investasi (Studi Pada Industri Manufaktur Yang Terdaftar Di Bursa Efek Indonesia). https://doi.org/10.31219/osf.io/cfb92

Alijoyo, A. dan S. Z. (2004). Komisaris Independen: Penggerak Praktek GCG di Perusahaan, PT. Indeks kelompok gramedia, Jakarta.

Baridwan, Z. (2003). Intermediate Accounting, Edisi Keempat, BPFE UGM, Yogyakarta.

Baridwan, Z. (2006). Sistem Akuntansi: Penyusunan Prosedur dan Metode, Edisi Kelima, Badan Penerbitan Fakultas Ekonomi, Yogyakarta.
Boediono. (2014). Seri Sinopsis Pengantar Ilmu Ekonomi No. 5 Ekonomi Makro. Yogyakarta: BPFE.

Cahyono, M. (2008). Pengaruh kualitas layanan terhadap kepuasan pelanggan brown salon di Tunjungan Plaza Surabaya. Bachelor thesis, Petra Christian University.

Effendy, O. U. (2009). Komunikasi teori dan praktek. Bandung: PT Remaja Rosdakarya.

Ferdinand, A. (2014). Metode Penelitian Manajemen, Semarang, Badan Penerbit Universitas Diponegoro.

Hasan., A. (2008). Marketing. Media Utama, Yogyakarta.

Herawaty, V. (2008). Peran Praktek Corporate Governance Sebagai Moderating Variabel dari Pengaruh Earning Management Terhadap Nilai Perusahaan. Jurnal Akuntansi dan Keuangan, Vol. 10 No. 2, November, 2008, hal: 97-108.

Indra Surya dan Ivan Yustiavandana. (2006). Penerapan Good Corporet Governance Mengesampingkan Hakhak Istimewa Demi Kelangsungan Uasaha. Jakarta : kencana.

Isnanta. Rudi. (2007). "Pengaruh Good Corporate Governance dan Struktur Kepemilikan terhadap Manajemen Laba dan Kinerja Perusahaan Universitas Sumatera Utara 63 Manufaktur di BEJ", Skripsi, Fakultas Ekonomi Universitas Islam Indonesia, Yogyakarta.

Mayliza, R. (2019). Pengaruh Good Corporate Governance Dan Leverage Terhadap Kinerja Keuangan Pada Perbankan Yang Terdaftar Di BEI. https://doi.org/10.17605/OSF.IO/M9 DT6 
Midiastuty., E. S. D. P. P. (2003). Analisis Pengaruh Harga, Kualitas Produk, dan Lokasi terhadap Keputusan Pembelian.

Putri, A. D., \& Mayliza, R. (2019). Pengaruh Good Corporate Governance Dan Leverage Terhadap Kinerja Keuangan Pada Perbankan Yang Terdaftar Di BEI. https://doi.org/10.31219/osf.io/b8he7 